\title{
Carvedilol suppresses malignant proliferation of mammary epithelial cells through inhibition of the ROS-mediated PI3K/AKT signaling pathway
}

\author{
ZHONGBING MA ${ }^{1}$, XINGLI LIU ${ }^{2}$, QIANG ZHANG ${ }^{1}$, ZHIGANG YU ${ }^{1}$ and DEZONG GAO ${ }^{1}$ \\ ${ }^{1}$ The Second Hospital of Shandong University, Jinan, Shandong 250033; \\ ${ }^{2}$ Qilu Children's Hospital of Shandong University, Jinan, Shandong 250040, P.R. China
}

Received February 4, 2018; Accepted November 8, 2018

DOI: $10.3892 /$ or.2018.6873

\begin{abstract}
Reactive oxygen species (ROS) cause oncogenic mutations through direct interaction with DNA. Carvedilol (CAR) exhibits antioxidative activity, and pre-clinical studies have identified that CAR may prevent malignant transformation in certain carcinogenic models. This suggests that CAR may be a potential agent in cancer prevention. In the present study, non-cancerous MCF-10A cells were used as a model to investigate the chemopreventive effect of CAR on benzo(a)pyrene (BaP)-induced cellular carcinogenesis. It was identified that CAR had the ability to eliminate BaP-induced ROS production and subsequent DNA damage. CAR/BaP activated the ROS-mediated phosphoinositide 3-kinase (PI3K)/protein kinase B (AKT) ${ }^{\mathrm{Thr} 308}$ signaling pathway, whereas the effectors of the PI3K/AKT signaling pathway, murine double minute 2 (MDM2) and $\mathrm{p} 53^{\text {Ser15 }}$, served important functions in the BaP/CAR-mediated MCF10A cellular transformation. The results of the present study indicated that CAR may be a novel chemopreventive agent, notably in the prevention of estrogen receptor-negative breast cancer. The antioxidant effects of CAR may contribute to its chemopreventive activity.
\end{abstract}

\section{Introduction}

Cancer is a disease that is characterized by various stages, including initiation, promotion and progression. It is known that cancer cells are characterized by an increased rate of reactive oxygen species (ROS) production, which enhances the tumor metabolic adaptation, proliferation and survival. Excess ROS cause oncogenic mutations through direct reaction with DNA,

Correspondence to: Dr Dezong Gao, The Second Hospital of Shandong University, 247 Beiyuan Street, Jinan, Shandong 250033, P.R. China

E-mail: gaohill100@yeah.net

Key words: carvedilol, cancer prevention, reactive oxygen species, phosphoinositide 3-kinase/protein kinase B signaling pathway thus ROS are believed to be among the initiating insults that drive carcinogenesis (1). At the initial stage of breast cancer, increased ROS levels may promote cell susceptibility to DNA damage induced by environmental carcinogens, contributing to chromosome instability and cellular carcinogenesis (2). Thus, strategies and drugs that are designed to decrease ROS levels would be effective in preventing the initiation of breast cancer.

Carvedilol (CAR), a non-selective adrenergic blocker, was primarily designed to treat cardiovascular disease by inhibiting adrenergic receptors (3). Results from a pre-clinical study indicated that CAR could inhibit the proliferation of cancer cells and induce cell apoptosis in vitro (4). Our previous study identified that CAR significantly decreased the migratory and invasive capacities of breast cancer cells (5). Furthermore, a population-based cohort study indicated that long-term treatment with CAR was associated with a decreased risk of cancer, indicating that CAR may be a potential agent in the prevention of certain types of cancer (6). Results from a pre-clinical study suggested that CAR may prevent malignant transformation in in vitro and in vivo models of skin carcinogenesis (7). These results imply that CAR may be a novel chemopreventive agent.

MCF-10A cells are non-cancerous cells, which are transformable and form colonies in soft agar following exposure to tumor promoters $(8)$. Benzo $(a)$ pyrene $(\mathrm{BaP})$ is able to transform MCF-10A cells into initiated breast cancer cells. This process is mediated via DNA adduct formation and ROS serve a crucial function in the initiation of carcinogenesis. Certain agents prevent tumorigenesis by their antioxidant activity (9). With the exception of the $\beta$-blocker effect, CAR exhibits antioxidant activity, but currently there is no knowledge of whether CAR is able to prevent breast cancer via oxidative resistance.

In the present study, non-cancerous MCF-10A cells were used as a model to investigate the chemopreventive effect of CAR on BaP-induced cellular carcinogenesis. The signaling pathways that were associated with CAR during the prevention of breast carcinogenesis were further investigated.

\section{Materials and methods}

Cells and reagents. Normal breast epithelial MCF-10A cells were purchased from the American Type Culture Collection 
(Manassas, VA, USA). BaP and CAR were purchased from Sigma; Merck KGaA (Darmstadt, Germany). These agents were prepared as $50 \mu \mathrm{M}$ stock solutions and were stored at $4^{\circ} \mathrm{C}$ in double-distilled water. Phenol red-free Dulbecco's modified Eagle's medium (DMEM)/Ham's F12, horse serum, penicillin/streptomycin, antibiotic/antimycotic, epidermal growth factor, human insulin (Novolin R), trypsin-EDTA (10X), Hanks' balanced salt solution and PBS were purchased from Invitrogen; Thermo Fisher Scientific, Inc. (Waltham, MA, USA). Cholera enterotoxin was obtained from Enzo Life Sciences, Inc. (Farmingdale, NY, USA). AKT inhibitor VIII and AKT phosphorylation activator SC79 were purchased from MedChemExpress (Monmouth Junction, NJ, USA). The human 8-hydroxy-2-deoxyguanosine (8-OH-dG) ELISA kit was purchased from Cusabio Technology LLC (Houston, TX, USA). All other chemicals were purchased from Sigma-Aldrich; Merck KGaA.

Cell culture. MCF10A cells were maintained in complete medium (1:1 mixture of DMEM and Ham's F12), supplemented with mitogenic additives including $5 \%$ horse serum, $10 \mu \mathrm{M}$ insulin, $0.5 \mathrm{ng} / \mathrm{ml}$ hydrocortisol, $20 \mathrm{ng} / \mathrm{ml}$ epidermal growth factor and $100 \mathrm{ng} / \mathrm{ml}$ cholera enterotoxin. The medium was also supplemented with $100 \mathrm{U} / \mathrm{ml}$ penicillin and $100 \mathrm{U} / \mathrm{ml}$ streptomycin. All cultures were maintained at $37^{\circ} \mathrm{C}$ under $5 \% \mathrm{CO}_{2}$.

Cell treatments and harvesting. $\mathrm{BaP}$ and $\mathrm{CAR}$ were initially dissolved in dimethylsulfoxide and subsequently in cell culture medium. All treatments were prepared and administered under low light conditions, prior to incubation at $37^{\circ} \mathrm{C}$ in a $5 \% \mathrm{CO}_{2}$ humidified incubator. MCF-10A cells were divided into three groups, namely $\mathrm{BaP}$ treatment, $\mathrm{CAR} / \mathrm{BaP}$ co-treatment and control. The BaP group was treated with $1 \mu \mathrm{mol} / 1 \mathrm{BaP}$ for $6,12,24$ or $36 \mathrm{~h}$. The CAR/BaP group was treated with $1 \mu \mathrm{mol} / 1 \mathrm{BaP}$ in combination with $0.5,1.0,5.0$ or $10 \mu \mathrm{mol} / \mathrm{l} \mathrm{CAR}$. The control group was cultured without CAR or $\mathrm{BaP}$. To determine the effect of $\mathrm{H}_{2} \mathrm{O}_{2}, \mathrm{MCF}-10 \mathrm{~A}$ cells were cultured with $\mathrm{H}_{2} \mathrm{O}_{2}(200 \mu \mathrm{mol} / \mathrm{l})$ and CAR $(5 \mu \mathrm{mol} / \mathrm{l})$ for $36 \mathrm{~h}$. The cells were harvested by trypsinization at $6,12,24$ or $36 \mathrm{~h}$, and were suspended in PBS without $\mathrm{Mg}^{2+}$ or $\mathrm{Ca}^{2+}$. The cells were snap-frozen at $-196^{\circ} \mathrm{C}$ in liquid $\mathrm{N}_{2}$ until further use.

Determination of intracellular ROS levels. The cultures were labeled with $5 \mu \mathrm{mol} / 1$ dichlorodihydrofluorescein diacetate for $1 \mathrm{~h}$. ROS levels were detected using flow cytometry (BD Biosciences, Franklin Lakes, NJ, USA) and fluorescence microscopy (Nikon Corporation, Tokyo, Japan). The cells were trypsinized from the cultures and resuspended in PBS for analysis of ROS, using a $15 \mathrm{~mW}$ air-cooled argon laser at an excitation wavelength of $488 \mathrm{~nm}$. Dichlorofluorescein fluorescence emission was determined using a $529 \mathrm{~nm}$ band pass filter. The mean fluorescence intensity of $2 \times 10^{4}$ cells was quantified using Multicycle AV software (version 3.0; Phoenix Flow Systems, San Diego, CA, USA).

Single cell gel electrophoresis (comet assay). MCF-10A cells were exposed to BaP/CAR for $48 \mathrm{~h}$ (one cycle) and/or exposed for between 5 and 20 cycles to induce cellular carcinogenesis (10). Cultured cells were harvested as aforementioned.
The comet assay was performed according to a previously published protocol (9), and tail moment was the indicator of DNA damage. Tail moment is defined as the product of the tail length and the fraction of total DNA in the tail, which can be calculated using commercially available and public domain software (9). Data analysis was performed using Komet software (version 5.5; Andor Technology, PLC, Belfast, Northern Ireland, UK), and Kinetic Imaging (version 5.0; Kinetic Imaging Ltd., Wirral, UK).

ELISA detection of 8-OH-dG in MCF-10A cells treated with BaP/CAR. The three groups of cells, namely $\mathrm{BaP}$ $(1 \mu \mathrm{M})$ treatment, CAR $(5 \mu \mathrm{M}) / \mathrm{BaP}(1 \mu \mathrm{M})$ co-treatment and control, were plated in 6 -well dishes at a density of $1 \times 10^{6}$ cells/dish cultured for $24 \mathrm{~h}$. The cells were trypsinized and resuspended in PBS. Subsequently, two freeze-thaw cycles were performed and the homogenates were centrifuged at 5,000 x g for $5 \mathrm{~min}$ at $4{ }^{\circ} \mathrm{C}$. The supernatant was removed and the 8-OH-dG levels were determined using the 8-OH-dG ELISA kit, according to the manufacturer's protocol. Absorbance was determined at $450 \mathrm{~nm}$ using Curve Expert Professional software (version 2.3.0; win.cutephp. com/curveexpert_professional_1996267) to create a standard curve. Results are expressed in $\mathrm{ng} / \mathrm{ml}$. Samples were assayed in a blind manner.

Western blot analysis. Cell lysates were prepared by washing cells with PBS and were incubated for $10 \mathrm{~min}$ at $4^{\circ} \mathrm{C}$ in modified radioimmunoprecipitation assay lysis buffer $[50 \mathrm{mmol} / 1$ Tris $/ \mathrm{HCl}, 150 \mathrm{mmol} / \mathrm{l} \mathrm{NaCl}, 1 \%$ Triton X-100, $0.5 \%$ sodium deoxycholate, $25 \mu \mathrm{g} / \mathrm{ml}$ leupeptin, $10 \mu \mathrm{g} / \mathrm{ml}$ aprotinin, $2 \mathrm{mmol} / \mathrm{l}$ EDTA and $1 \mathrm{mmol} / \mathrm{l}$ sodium orthovanadate (Sigma; Merck $\mathrm{KGaA})]$. The cells were scraped from the plates and centrifuged at 5,000 $\mathrm{xg}$ for $20 \mathrm{~min}$ at $4^{\circ} \mathrm{C}$, and the supernatants were collected. The protein concentration levels were determined using a Bicinchoninic Acid assay kit (Pierce; Thermo Fisher Scientific, Inc.), and $40 \mu \mathrm{g}$ whole cell lysates were separated by SDS-PAGE (10\% gels). The samples were transferred onto a nitrocellulose membrane by wet blotting. The membrane was blocked with 5\% fat-free dry milk in PBS for $1 \mathrm{~h}$ at room temperature, and incubated with primary antibodies overnight at $4^{\circ} \mathrm{C}$. The antibodies used were anti-phospho (p)-AKT $\left(\mathrm{Thr}^{308}\right)$ (1:400; cat. no. 558316; BD Biosciences), anti-murine double minute 2 (MDM2; 1:400; cat. no. 556353; BD Biosciences), anti-p-p53 $\left(\mathrm{Ser}^{15} / \mathrm{Ser}^{20}\right)(1: 100$; cat. no. sc-10176; Santa Cruz Biotechnology, Inc., Dallas, TX, USA) and anti- $\beta$-arrestin (1:100; cat. no. sc-21872; Santa Cruz Biotechnology, Inc.). Following three washes with PBS, the membrane was incubated with goat anti-mouse immunoglobulin $\mathrm{G}(\operatorname{IgG})$ (1:8,000; cat. no. 31430; Thermo Fisher Scientific, Inc.) and goat anti-rabbit IgG $(1: 8,000$; cat. no. 31460 ; Thermo Fisher Scientific, Inc.) secondary antibodies and visualized with SuperSignal West Dura Extended Duration Substrate (Thermo Fisher Scientific, Inc.).

Statistical analysis. Unless indicated otherwise, each assay was conducted three times. Results are presented as the mean \pm standard error of the mean. Results were analyzed by one-way analysis of variance or Student's t-test; multiple comparisons between the groups were performed using the 


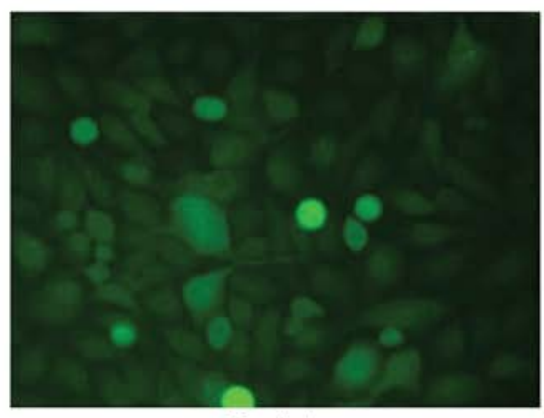

Control

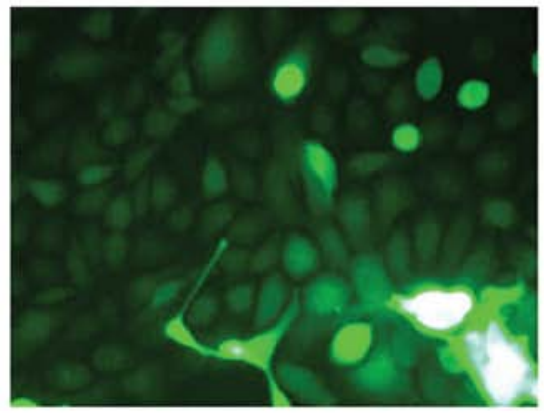

BaP $1.0 \mu \mathrm{M}+\mathrm{CAR} 1.0 \mu \mathrm{M}$

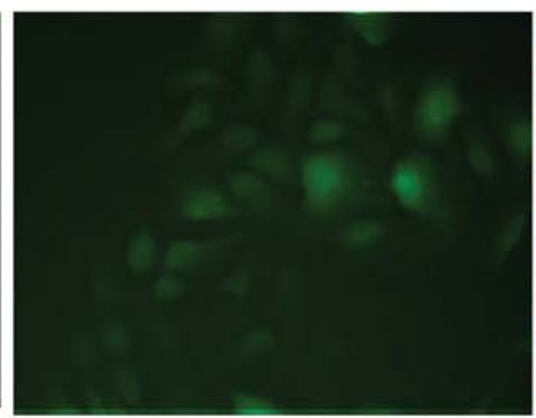

CAR $10 \mu \mathrm{M}$

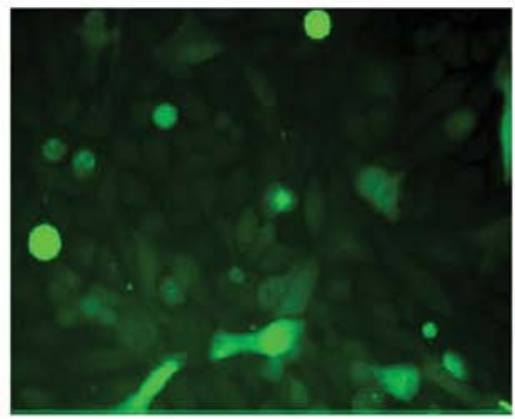

$\mathrm{BaP} 1.0 \mu \mathrm{M}+\mathrm{CAR} 5.0 \mu \mathrm{M}$

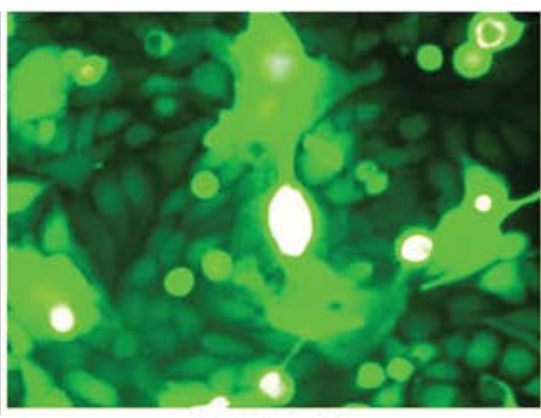

$\mathrm{BaP} 1.0 \mu \mathrm{M}$

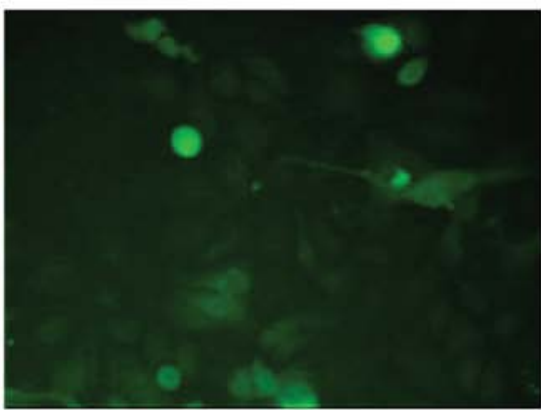

$\mathrm{BaP} 1.0 \mu \mathrm{M}+\mathrm{CAR} 10 \mu \mathrm{M}$

Figure 1. CAR inhibits BaP-induced ROS generation. MCF-10A cells were exposed to BaP (1 $\mu \mathrm{M})$ with or without CAR (1, 5 or $10 \mu \mathrm{M})$ for $24 \mathrm{~h}$ and the cells were labeled with dichlorodihydrofluorescein diacetate $(5 \mu \mathrm{M})$. The images were obtained by fluorescence. CAR, carvedilol; BaP, benzo $(a)$ pyrene; ROS, reactive oxygen species.

Student-Newman-Keuls method. $\mathrm{P}<0.05$ was considered to indicate a statistically significant difference.

\section{Results}

CAR inhibits BaP-induced ROS production. BaP induces DNA damage through the generation of ROS, which initiate oxidative damage to nucleic acids (2). In addition to the $\beta$-blocker effect, CAR acts as an antioxidant and a ROS scavenger (11). MCF-10A cells were used in order to investigate the effects of CAR on BaP-mediated ROS production. In the absence of $\mathrm{BaP}, \mathrm{MCF}-10 \mathrm{~A}$ cells generated ROS spontaneously, and CAR had the potential to decrease ROS production in cells that were not treated with $\mathrm{BaP}$ (Fig. 1). BaP increased ROS production in MCF-10A cells; however, CAR, at concentrations $\geq 1 \mu \mathrm{M}$, attenuated BaP-induced ROS production in a dose-dependent manner (Fig. 2, upper panel). Short-term exposure $(6 \mathrm{~h})$ of MCF-10A cells to $1 \mu \mathrm{M}$ BaP induced ROS, and ROS production reached a peak at $24 \mathrm{~h}$ (Fig. 2, lower panel). BaP induced a significant increase in ROS levels in a time-dependent manner (between 6 and $24 \mathrm{~h}$ ), although ROS levels decreased at $36 \mathrm{~h}$, indicating endogenous adjustment (Fig. 2). Co-treatment of CAR and BaP decreased BaP-induced ROS production at all time points investigated in a dose-dependent manner (CAR concentration $\geq 1 \mu \mathrm{M}$ ) (Figs. 1 and 2 ).

CAR eliminates BaP-induced DNA damage. BaP induced significant DNA damage as demonstrated using the alkaline comet assay in MCF-10A cells. Exposure of the cells to $\mathrm{BaP}$ for 5 cycles was sufficient to induce DNA strand breaks in MCF-10A cells, although no DNA damage was observed in the 15-20 exposure cycles using the alkaline comet assay.
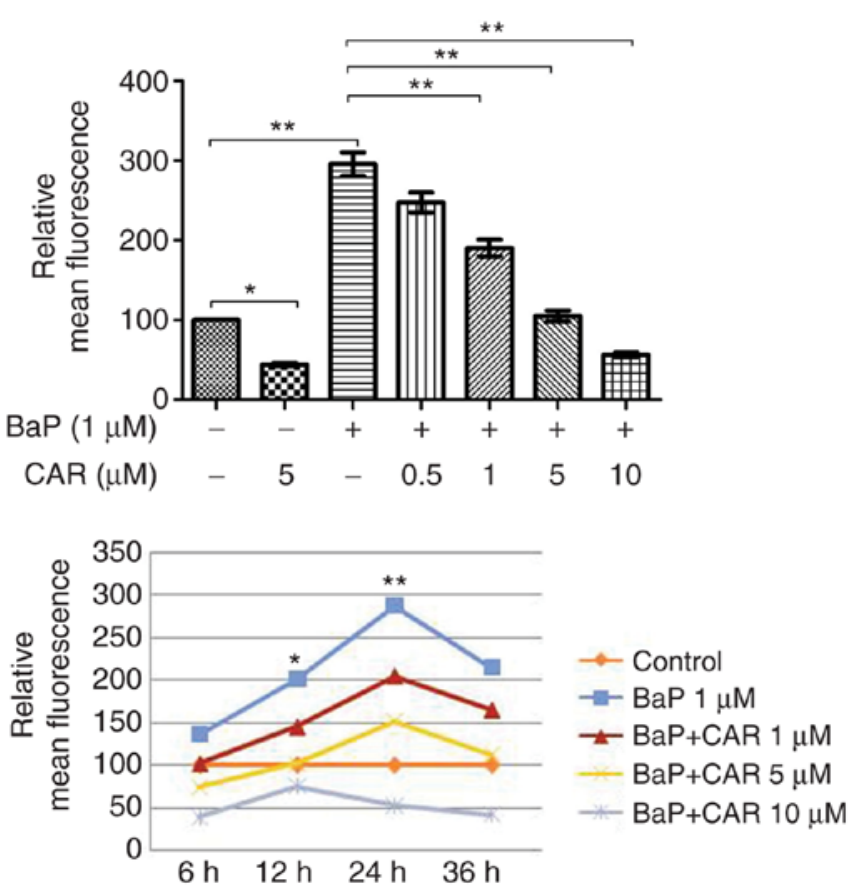

Figure 2. Fluorescence intensity of ROS was determined in MCF-10A cells treated with $\mathrm{BaP}$ and/or CAR using flow cytometry. Results are expressed as the mean \pm standard deviation of three independent experiments. ${ }^{*} \mathrm{P}<0.05$, ${ }^{* *} \mathrm{P}<0.01$ vs. BaP treatment for $6 \mathrm{~h}$. CAR, carvedilol; ROS, reactive oxygen species; $\mathrm{BaP}$, benzo $(a)$ pyrene.

Treatment of the cells with $1 \mu \mathrm{M}$ BaP caused DNA damage at 12,24 and $36 \mathrm{~h}$ of culture, compared with control cells; however, CAR attenuated DNA strand breaks that were induced by $\mathrm{BaP}$ (Fig. 3A). A concentration-dependent effect 

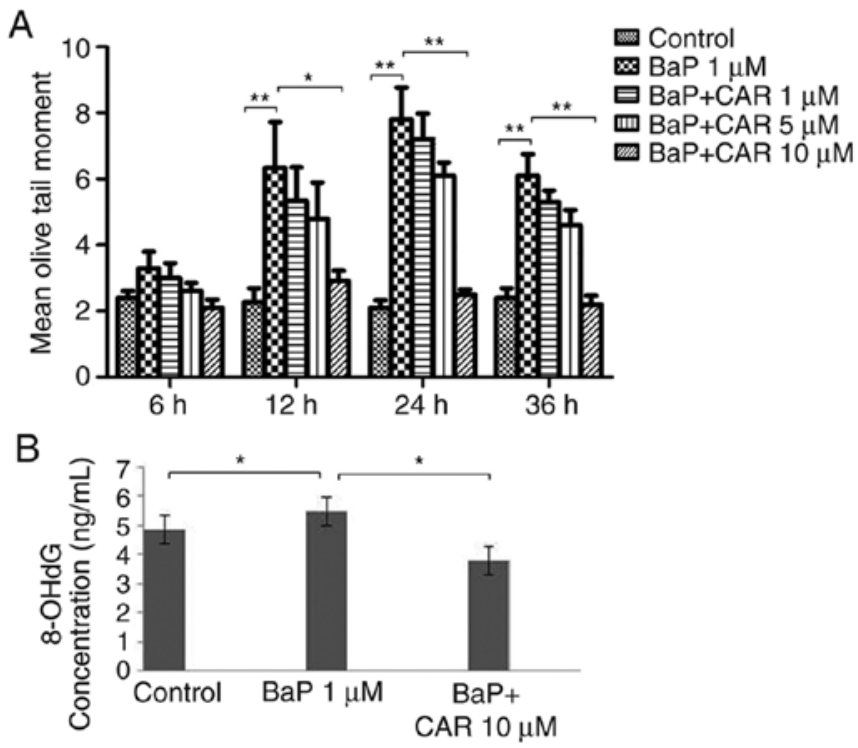

Figure 3. CAR decreases BaP-induced DNA strand breaks and 8-OH-dG concentration. MCF-10A cells were treated with $\mathrm{BaP}(1 \mu \mathrm{M})$ and CAR $(1,5$ and $10 \mu \mathrm{M})$ for different durations. (A) DNA damage was analyzed using the comet assay. The results present the mean olive tail moment, an indicator of DNA damage, \pm standard error of the mean for 100 cells $(n=3)$. (B) 8-OH-dG was detected using ELISA in cells treated with $1 \mu \mathrm{M} \mathrm{BaP}$ with or without $10 \mu \mathrm{M}$ CAR. ${ }^{*} \mathrm{P}<0.05,{ }^{* *} \mathrm{P}<0.01$. BaP, benzo $(a)$ pyrene; $8-\mathrm{OH}-\mathrm{dG}$, 8-hydroxy-2-deoxyguanosine; CAR, carvedilol.

was observed using CAR. Treatment of the cells with $10 \mu \mathrm{M}$ $\mathrm{CAR}$ and $\mathrm{BaP}$ for $24 \mathrm{~h}$ attenuated $68 \%$ of BaP-induced DNA damage (data not shown), which corresponded nearly to the levels of the control group (Fig. 3A). As a marker of DNA oxidative damage, 8-OH-dG levels increased in MCF-10A cells treated with $\mathrm{BaP}$ determined using the $8-\mathrm{OH}-\mathrm{dG}$ ELISA kit, although CAR reversed the effect of BaP (Fig. 3B). Cells cultured with $1 \mu \mathrm{M}$ BaP for $24 \mathrm{~h}$ exhibited apparent DNA damage, and CAR and AKT inhibitor VIII eliminated DNA damage caused by $\mathrm{BaP}$ (Fig. 4). These results indicated that CAR has the ability to inhibit BaP-induced DNA damage.

CAR inhibition of BaP induces the PI3K/AKT signaling pathway via the decrease in ROS production. Certain carcinogens induce intracellular ROS accumulation, and increase the expression of PI3K and AKT proteins. ROS also directly activate PI3K, and activated PI3K further phosphorylates its downstream target AKT. The alterations in the PI3K/AKT signaling pathway have been revealed to promote cell survival and proliferation $(12,13)$. In order to investigate the mechanism of CAR suppression in BaP-induced MCF-10A cell carcinogenesis, the level of expression and phosphorylation of target proteins associated with the PI3K/AKT signaling pathway was determined. Western blot analysis using an antibody against p-(activated) $\mathrm{AKT}^{\mathrm{Th} r 308}$ indicated that, compared with untreated cells, $\mathrm{p}-\mathrm{AKT}^{\mathrm{Th}} 308$ expression was increased significantly in MCF-10A cells that were treated with BaP. When cells were incubated with CAR $(5 \mu \mathrm{M})$ and BaP simultaneously for various durations, $\mathrm{p}-\mathrm{AKT}^{\mathrm{Thr} 308}$ expression decreased in all cases (Fig. 5A). These results suggested that AKT phosphorylation induced by BaP could be inhibited by CAR in MCF-10A cells. However, AKT (non-phosphorylated) expression was

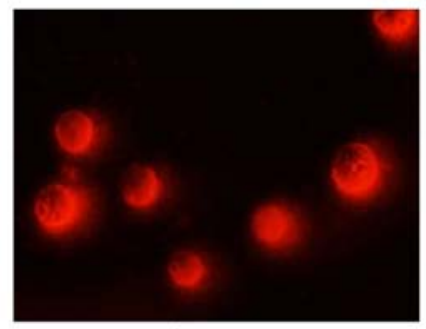

Control

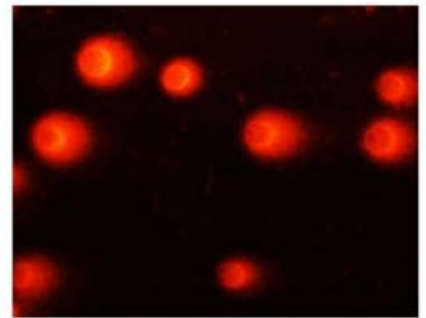

BaP $1.0 \mu \mathrm{M}+\mathrm{CAR} 5.0 \mu \mathrm{M}$

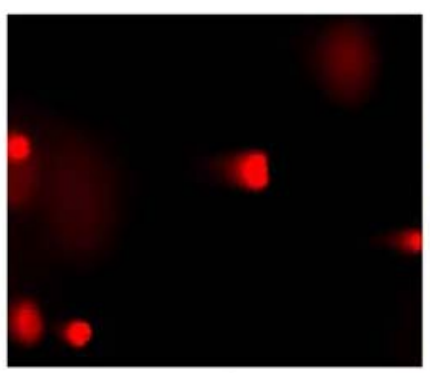

$\mathrm{BaP} 1.0 \mu \mathrm{M}+\mathrm{CAR} 1.0 \mu \mathrm{M}$

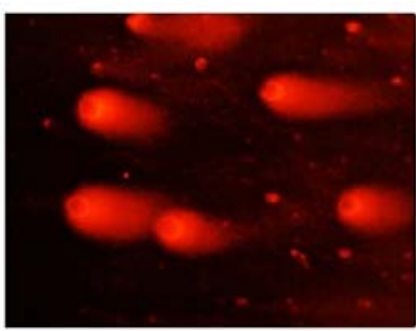

$\mathrm{BaP} 1.0 \mu \mathrm{M}$

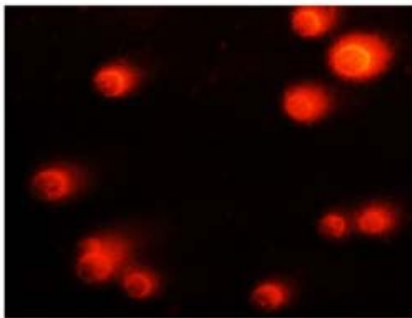

BaP 1.0 $\mu \mathrm{M}+\mathrm{AKT}$ inhibitor VIII

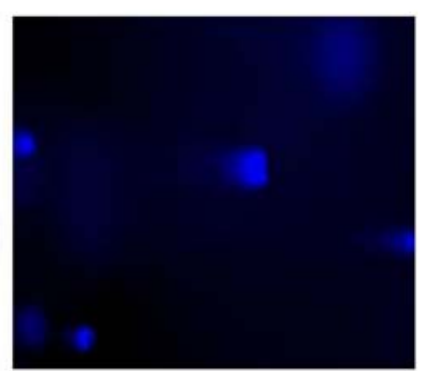

DAPI
Figure 4. CAR decreases BaP-induced DNA strand breaks in MCF-10A cells as determined using the comet assay. Cells were cultured with $1 \mu \mathrm{M} \mathrm{BaP}$ for $24 \mathrm{~h}$ and exhibited apparent DNA damage. CAR and AKT inhibitor VIII eliminated DNA damage caused by BaP. Blue (excitation, $330 \mathrm{~nm}$; emission, $420 \mathrm{~nm}$ ) indicates nuclei (DAPI staining). CAR, carvedilol; $\mathrm{BaP}$, benzo(a)pyrene; AKT, protein kinase $\mathrm{B}$.

not influenced by treatment with BaP and CAR for $24 \mathrm{~h}$ (Fig. 5B). However, in the absence of BaP, MCF-10A cells were co-cultured with $\mathrm{H}_{2} \mathrm{O}_{2}$ and CAR, and p-AKT ${ }^{\mathrm{Th} 308}$ expression increased markedly (data not shown). These results indicated that CAR inhibited BaP-induced PI3K/AKT activation via the inhibition of ROS generation, but not ROS scavenging.

CAR inhibition of BaP causes a change in MDM2 and p53 expression levels. MDM2 is an important AKT substrate. Phosphorylation of MDM2 by AKT can target the tumor suppressor p53 for degradation through ubiquitination. p53 modulates cells that are under oxidative stress and aids the adaptation of the cell's oxidative mechanism to the remodeled redox balance, thus preventing oxidative damage to DNA and proteins $(14,15)$. Therefore, the effect of CAR on the expression of $\mathrm{p} 53^{\mathrm{Ser} 15}$, $\mathrm{p} 53^{\mathrm{Ser} 20}$ and MDM2 in BaP-induced cells was investigated by western blotting. As CAR suppresses BaP-induced neoplastic activity and associated protein function at concentrations between 1 and $10 \mu \mathrm{M}, 5 \mu \mathrm{M}$ CAR was used as the optimal concentration. It was identified that MDM2 expression was upregulated in BaP-treated cells, although CAR was able to eliminate the effects of BaP (Fig. 5C). In addition, the expression of $\mathrm{p} 53^{\mathrm{Ser} 15}$ was downregulated in BaP-treated cells, although CAR could prevent the influence 
A
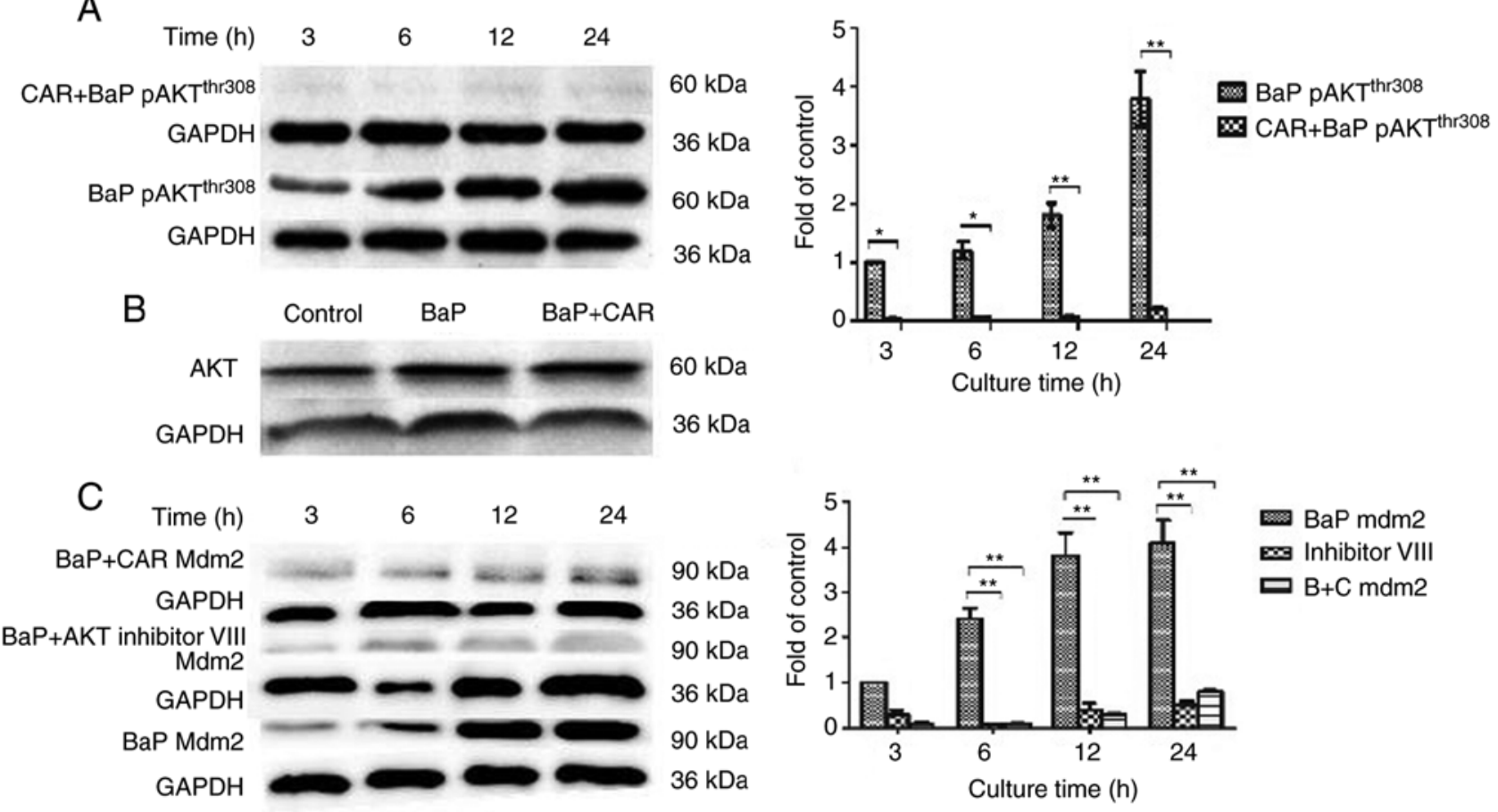

Figure 5. Cell lysates were prepared and analyzed by western blotting to determine the levels of (A) AKT ${ }^{\text {Thr308 }}$, (B) AKT and (C) MDM2, with GAPDH used as a control. The levels of pAKT ${ }^{\mathrm{Th} 308}, \mathrm{MDM} 2, \mathrm{p} 53^{\mathrm{Ser} 15}$ and GAPDH were quantified by densitometry. All results are representative of three independent experiments. ${ }^{*} \mathrm{P}<0.05,{ }^{* *} \mathrm{P}<0.01$. AKT, protein kinase B; MDM2, murine double minute 2; BaP, benzo $(a)$ pyrene; CAR, carvedilol.
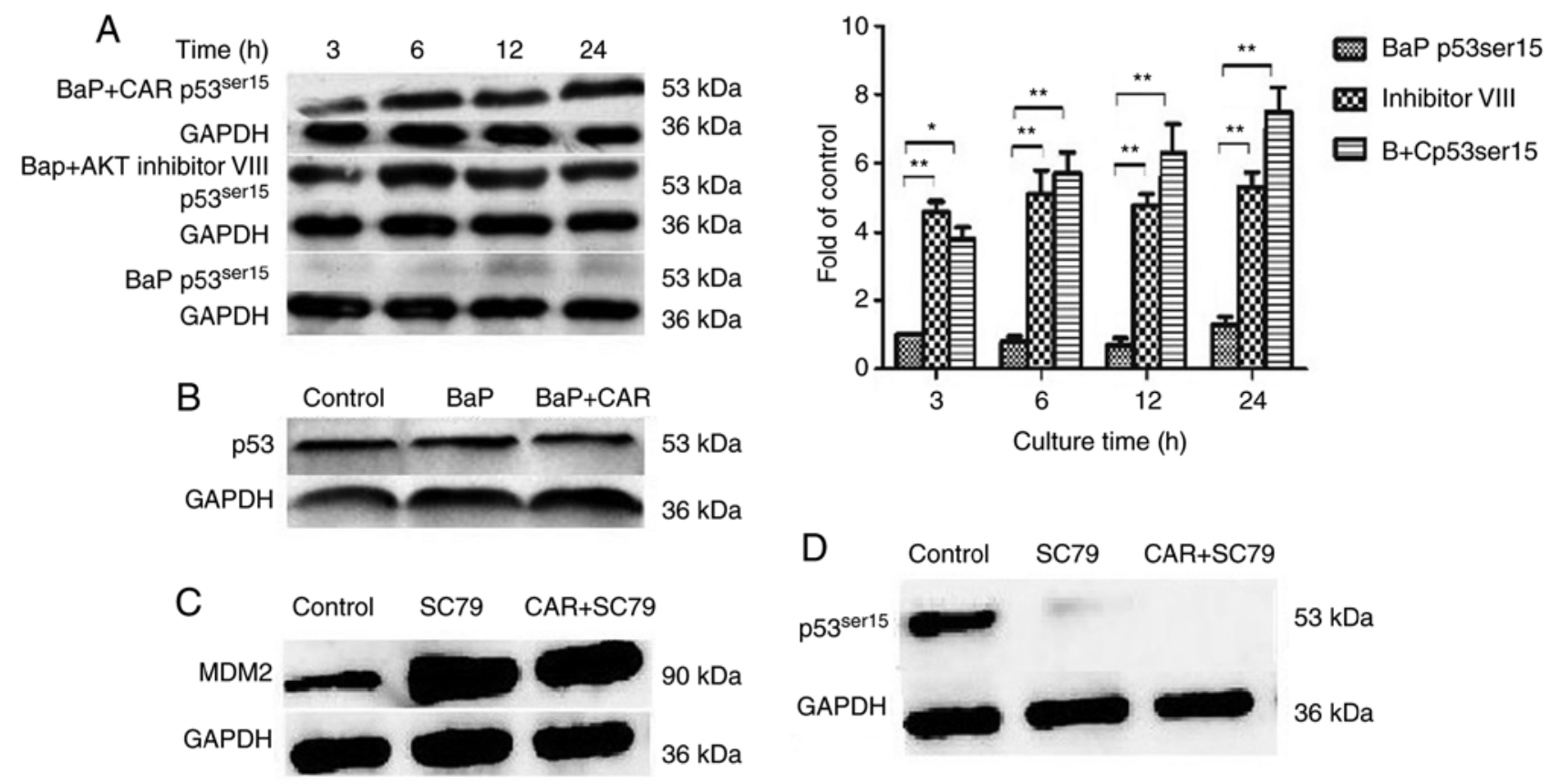

Figure 6. Cell lysates were prepared and analyzed by western blotting to determine the levels of (A) p53 ${ }^{\text {Ser15 }}$ and (B) p53, with GAPDH used as a control. The levels of $\mathrm{p} 53^{\text {Serl5 } 5}$ and GAPDH were quantified by densitometry. All results are representative of three independent experiments. ${ }^{*} \mathrm{P}<0.05$, ${ }^{* *} \mathrm{P}<0.01$. Cells were cultured with and without CAR/SC79 for $24 \mathrm{~h}$, and cell lysates were prepared and analyzed by western blotting to detect the levels of (C) MDM2 and (D) $\mathrm{p}^{\text {Ser15 }}$, with GAPDH as a control. CAR, carvedilol; MDM2, murine double minute 2; BaP, benzo(a)pyrene; AKT, protein kinase B; B+C, BaP and CAR .

of $\mathrm{BaP}$, and eliminate these changes caused by $\mathrm{BaP}$ at the time points investigated (Fig. 6A). However, p53 ${ }^{\mathrm{Ser} 20}$ expression did not alter in BaP-treated cells (data not shown). Furthermore, p53 (non-phosphorylated) expression was not influenced when cells were treated with BaP and CAR for $24 \mathrm{~h}$ (Fig. 6B). As effectors of the PI3K/AKT signaling pathway, the MDM2 and p53 ${ }^{\mathrm{Ser} 15}$ proteins serve important functions in the effects of $\mathrm{BaP} / \mathrm{CAR}$ on MCF-10A cell transformation.

When MCF-10A cells were co-cultured with BaP and the AKT inhibitor VIII, BaP had no influence on 
MDM2 expression and p53 degradation (Figs. 5C and 6A). Furthermore, BaP-induced DNA damage was counteracted by the AKT inhibitor VIII as demonstrated using the alkaline comet assay (Fig. 4). In contrast with the inhibition of AKT, when cells were treated with CAR and SC79 (an AKT phosphorylation activator), enhanced MDM2 expression and p53 degradation were evident from western blot analysis (Fig. 6C and D). CAR was not able to inhibit the effects of SC79, which indicated that CAR acts upstream of the PI3K/AKT signaling pathway. These data indicated that BaP-induced ROS production activated PI3K/AKT, which in turn upregulated MDM2, thus facilitating p53 degradation. CAR prevents cellular carcinogenesis induced by $\mathrm{BaP}$ via the suppression of PI3K/AKT and MDM2 activity, which increases p53 levels in MCF-10A cells.

\section{Discussion}

ROS are free radicals with marked oxidative activity. ROS oxidize proteins and DNA, and damage various cellular organelles. This initiates the cellular injury responsible for aging and disease (16). ROS-mediated DNA damage can promote the malignant transformation of cells, and facilitate cell survival and proliferation (17-20). Increases in ROS may promote cell susceptibility to DNA damage induced by carcinogens, contributing to cellular carcinogenesis (21). However, the exact function of ROS in BaP-induced carcinogenesis of breast pre-cancerous cells is unclear.

CAR is a non-selective adrenergic blocker, primarily designed to treat cardiovascular disease by blocking adrenergic receptors. CAR is licensed by the US Food and Drug Administration for the treatment of chronic heart failure partly due to its antioxidant and ROS-scavenging properties (22). In addition, CAR has the potential of anti-neoplastic action, including breast cancer and glioma (4). In our previous study, we identified that CAR could inhibit migration and invasion of several breast cancer cell lines (5). A recent study indicated that CAR could prevent skin carcinogenesis induced by DMBA (7). However, there are no studies regarding the potential prevention of breast cancer by CAR. To address this question and to investigate the mechanisms of CAR in eliminating the activity of $\mathrm{BaP}$ in cellular carcinogenesis, CAR activity in the modulation of BaP-induced increases in ROS, DNA damage, and associated signaling pathways in pre-cancerous breast cells were determined.

It was identified that $\mathrm{BaP}$ induced a significant and sustained increase in ROS levels in MCF-10A cells, and that CAR attenuated BaP-induced ROS production in a concentration-dependent manner at doses $\geq 1 \mu \mathrm{M}$. Furthermore, CAR was able to decrease ROS production in MCF-10A cells that were not treated with $\mathrm{BaP}$, since the cells could generate ROS spontaneously. ROS are associated with clustered DNA damage, chromosomal aberrations and induction of carcinogenesis in normal breast cells (23). The alkaline comet assay and $8-\mathrm{OH}-\mathrm{dG}$ ELISA kit were used to investigate the detection of DNA damage. The data demonstrated that BaP induced significant DNA damage, and that CAR could attenuate DNA strand breaks induced by $\mathrm{BaP}$ at the time points investigated. Compared with low-dose CAR treatment, the tail moment was lower in the high-dose CAR groups. In the present study, exposure of MCF-10A cells to $1 \mu \mathrm{M}$ BaP for 5 cycles was identified to be sufficient to induce DNA damage. However, no DNA damage was detected by the alkaline comet assay and $8-\mathrm{OH}-\mathrm{dG}$ detection, when cells were exposed to $\mathrm{BaP}$ for 10-20 cycles. It was identified that the single treatment of MCF-10A cells with a high concentration of $\mathrm{BaP}$ for $48 \mathrm{~h}$ was sufficient to cause chromosomal aberrations (24). Thus, we hypothesized that $\mathrm{MCF}-10 \mathrm{~A}$ cells treated with $\mathrm{BaP}$ for $>10$ cycles may progress to cancerous cells, whereas BaP exhibited no effects on the cancer cells. The investigation of the malignant transformation of the cells requires further investigation.

Alterations in the PI3K/AKT pathway have been observed in various types of tumor (25). Pre-cancerous cells chronically exposed to carcinogens increase their ROS production, which mediates the activation of PI3K, AKT and target proteins, resulting in increased cell proliferation and anchorage-independent growth (12). The aforementioned results led to the investigation of whether the PI3K/AKT signaling pathway may be involved in breast carcinogenesis induced by BaP. Phosphorylation at $\mathrm{Thr}^{308}$ and/or $\mathrm{Ser}^{473}$ indicates the activation of AKT (26). Vincent et al (27) hypothesized that the phosphorylation of $\mathrm{Thr}^{308}$ is a more reliable biomarker for the activity of AKT compared with phosphorylation of $\mathrm{Ser}^{473}$. In the present study, it was identified that chronic exposure to BaP could induce AKT ${ }^{\mathrm{Thr} 308}$ phosphorylation in MCF-10A cells, although the function of $\mathrm{BaP}$ was inhibited by $\mathrm{CAR}$ via inhibition of ROS production. In contrast with $\mathrm{BaP}, \mathrm{H}_{2} \mathrm{O}_{2}$ treatment of cells led to AKT activation, and CAR had no influence. This suggested that CAR inhibited BaP-induced PI3K/AKT activation through the inhibition of ROS generation, but not through ROS scavenging. The p53 gene may lose its repair activity and permit passage of DNA mutations from one generation to the next. This increases the risk of cell carcinogenesis to stress and damage. MDM2 is a downstream substrate of PI3K/AKT and degrades p53 to promote tumorigenesis (28). Following DNA damage, p53 can be activated, leading to the repair of DNA damage (29). The ability of PI3K/AKT activation to increase DNA damage by carcinogens in MCF-10A cells led us to hypothesize that BaP/CAR may affect the ability of MDM2 and $\mathrm{p} 53$. The results of the present study indicate that $\mathrm{BaP}$ could not increase the levels of p53 in MCF-10A cells. A possible reason may be that increased ROS induced by $\mathrm{BaP}$ activate AKT and subsequent MDM2, and activated MDM2 degrades p53 by ubiquitination in MCF-10A cells. The lack of $\mathrm{p} 53$ response by $\mathrm{BaP}$ in $\mathrm{MCF}-10 \mathrm{~A}$ cells suggested that $\mathrm{p} 53$ had no protective functions on DNA damage in these cells; this may, in part, contribute to the potent mammary carcinogenicity of BaP. However, in the presence of CAR or AKT inhibitor VIII, the expression of p53 in MCF-10A treated with BaP was unknown. Generally, $\operatorname{Ser}^{15}$ and $\mathrm{Ser}^{20}$ in $\mathrm{p} 53$ are typically phosphorylated with DNA damage, and $\mathrm{Ser}^{15}$ is the most common site of phosphorylation (30-32). Therefore, antibodies against p-p53 at $\operatorname{Ser}^{15}$ and $\operatorname{Ser}^{20}$ to detect p53 activity by western blotting. It was identified that $\mathrm{p}$-p $53^{\text {Ser15 }}$ expression, but not $\mathrm{p}-\mathrm{p} 53^{\mathrm{Ser} 20}$, was upregulated in the presence of CAR or AKT inhibitor VIII in MCF-10A cells treated by BaP. This suggests that AKT activity (caused by ROS/BaP) was inhibited by CAR or AKT inhibitor VIII, subsequent 
MDM2 phosphorylation by p-AKT did not occur. Therefore, p5 $5{ }^{\text {Ser15 }}$ protein could not be degraded by MDM2 through ubiquitination.

Mitogen-induced activation of PI3K and its downstream target, AKT, results in phosphorylation of MDM2 on $\mathrm{Ser}^{166}$ and $\mathrm{Ser}^{186}$. Phosphorylation of these residues is necessary for translocation of MDM2 from the cytoplasm into the nucleus (28). Mutation of the AKT phosphorylation sites in MDM2 produces a mutant protein that is unable to enter the nucleus and increases p53 activity (28). Zhou et al (33) reported that AKT physically associates with MDM2 and phosphorylates it at $\mathrm{Ser}^{166}$ and Ser ${ }^{186}$. Phosphorylation of MDM2 enhances its nuclear localization and increases p53 degradation (33). The results of the present study identified that MDM2 expression was upregulated, although without detection of p-MDM2, as the downstream target of PI3K, phosphorylation of MDM2 by activated AKT is highly likely. Thus, increased MDM2 expression or phosphorylated MDM2 enhanced p53 degradation and may induce carcinogenesis in MCF10A cells. The results concerning the PI3K/AKT/MDM2 signaling pathway provided sufficient evidence for the function of CAR in the prevention of breast tumorigenesis.

Chemoprevention has become an important approach for decreasing breast cancer morbidity and mortality (34). Tamoxifen and raloxifene are the classical chemopreventive drugs used to prevent estrogen receptor (ER)-positive breast cancer that have minimal effects on ER-negative breast cancer (34). The results of the present study indicate that CAR may be considered a novel chemopreventive agent, notably in the prevention of ER-negative breast cancer, since MCF-10A cells rarely express ER (35). The antioxidant effect of CAR may contribute to its cancer-preventive activity. Although the present study focused on breast cancer prevention, the results may lay the foundation for clinical trials that can be designed to prevent other types of cancer, as reported recently in the prevention of hepatocarcinogenesis (36).

\section{Acknowledgements}

We are grateful to Dr Shuya Huang and Dr Chunmiao Ye for image editing.

\section{Funding}

The present study was supported by the Science and Technology Office of Shandong, with funding obtained from Shandong Natural Science Funds, China (grant nos. ZR2015HM043 and ZR2014HL074).

\section{Availability of data and materials}

The datasets used or analyzed during the current study are available from the corresponding author on reasonable request.

\section{Authors' contributions}

DG conceived and designed the experiments. XL performed the experiments. QZ and ZY analyzed and interpreted the data. $\mathrm{ZM}$ was involved in the conception of the study and wrote the manuscript. All authors read and approved the final manuscript.

\section{Ethics approval and consent to participate}

Not applicable.

\section{Patient consent for publication}

Not applicable.

\section{Competing interests}

The authors declare that they have no competing interests.

\section{References}

1. Wu Q and Ni X: ROS-mediated DNA methylation pattern alterations in carcinogenesis. Curr Drug Targets 16: 13-19, 2015.

2. Cooke MS, Evans MD, Dizdaroglu M and Lunec J: Oxidative DNA damage: Mechanisms, mutation, and disease. FASEB J 17: 1195-1214, 2003.

3. Oliveira PJ, Goncalves L, Monteiro P, Providencia LA and Moreno AJ: Are the antioxidant properties of carvedilol important for the protection of cardiac mitochondria? Curr Vasc Pharmacol 3: 147-158, 2005.

4. Erguven M, Yazihan N, Aktas E, Sabanci A, Li CJ, Oktem G and Bilir A: Carvedilol in glioma treatment alone and with imatinib in vitro. Int J Oncol 36: 857-866, 2010.

5. Dezong G, Zhongbing M, Qinye F and Zhigang Y: Carvedilol suppresses migration and invasion of malignant breast cells by inactivating Src involving cAMP/PKA and PKC signaling pathway. J Cancer Res Ther 10: 998-1003, 2014.

6. Lin CS, Lin WS, Lin CL and Kao CH: Carvedilol use is associated with reduced cancer risk: A nationwide population-based cohort study. Int J Cardiol 184: 9-13, 2015.

7. Chang A, Yeung S, ThakkarA,Huang KM,Liu MM,KanassategaRS, Parsa C, Orlando R, Jackson EK, Andresen BT, et al: Prevention of skin carcinogenesis by the $\beta$-blocker carvedilol. Cancer Prev Res (Phila) 8: 27-36, 2015.

8. Kastrati I, Edirisinghe PD, Hemachandra LP, Chandrasena ER, Choi J, Wang YT, Bolton JL and Thatcher GR: Raloxifene and desmethylarzoxifene block estrogen-induced malignant transformation of human breast epithelial cells. PLoS One 6: e27876, 2011.

9. Nkrumah-Elie YM, Reuben JS, Hudson A, Taka E, Badisa R, Ardley T, Israel B, Sadrud-Din SY, Oriaku E and Darling-Reed SF: Diallyl trisulfide as an inhibitor of benzo(a) pyrene-induced precancerous carcinogenesis in MCF-10A cells. Food Chem Toxicol 50: 2524-2530, 2012.

10. Song X, Siriwardhana N, Rathore K, Lin D and Wang HC: Grape seed proanthocyanidin suppression of breast cell carcinogenesis induced by chronic exposure to combined 4-(methylnitrosamino) -1-(3-pyridyl)-1-butanone and benzo[a]pyrene. Mol Carcinog 49: $450-463,2010$

11. Yue TL, McKenna PJ, Lysko PG, Gu JL, Lysko KA, Ruffolo RR Jr and Feuerstein GZ: SB211475, a metabolite of carvedilol, a novel antihypertensive agent, is a potent antioxidant. Eur J Pharmacol 251: 237-243, 1994.

12. Mohapatra P, Preet R, Das D, Satapathy SR, Siddharth S, Choudhuri T, Wyatt MD and Kundu CN: The contribution of heavy metals in cigarette smoke condensate to malignant transformation of breast epithelial cells and in vivo initiation of neoplasia through induction of a PI3K-AKT-NFKB cascade. Toxicol Appl Pharmacol 274: 168-179, 2014.

13. Son YO, Pratheeshkumar P, Wang L, Wang X, Fan J, Kim DH, Lee JY, Zhang Z, Lee JC and Shi X: Reactive oxygen species mediate $\mathrm{Cr}(\mathrm{VI})$-induced carcinogenesis through PI3K/AKT-dependent activation of GSK-3 $\beta / \beta$-catenin signaling. Toxicol Appl Pharmacol 271: 239-248, 2013.

14. Astle MV, Hannan KM, Ng PY, Lee RS, George AJ, Hsu AK, Haupt Y, Hannan RD and Pearson RB: AKT induces senescence in human cells via mTORC1 and p53 in the absence of DNA damage: Implications for targeting mTOR during malignancy. Oncogene 31: 1949-1962, 2012.

15. He J, Zhu G, Gao L, Chen P, Long Y, Liao S, Yi H, Yi W, Pei Z, Wu M, et al: Fra-1 is upregulated in gastric cancer tissues and affects the PI3K/Akt and p53 signaling pathway in gastric cancer. Int J Oncol 47: 1725-1734, 2015. 
16. Wojtovich AP and Foster TH: Optogenetic control of ROS production. Redox Biol 2: 368-376, 2014.

17. Gupta SC, Hevia D, Patchva S, Park B, Koh W and Aggarwal BB: Upsides and downsides of reactive oxygen species for cancer: The roles of reactive oxygen species in tumorigenesis, prevention, and therapy. Antioxid Redox Signal 16: 1295-1322, 2012.

18. Zhang C, Cao S, Toole BP and Xu Y: Cancer may be a pathway to cell survival under persistent hypoxia and elevated ROS: A model for solid-cancer initiation and early development. Int $\mathbf{J}$ Cancer 136: 2001-2011, 2015.

19. Cichon MA and Radisky DC: ROS-induced epithelial-mesenchymal transition in mammary epithelial cells is mediated by $\mathrm{NF}-\kappa \mathrm{B}-$ dependent activation of Snail. Oncotarget 5: 2827-2838, 2014.

20. Nourazarian AR, Kangari P and Salmaninejad A: Roles of oxidative stress in the development and progression of breast cancer. Asian Pac J Cancer Prev 15: 4745-4751, 2014.

21. Pluchino LA, Liu AK and Wang HC: Reactive oxygen species-mediated breast cell carcinogenesis enhanced by multiple carcinogens and intervened by dietary ergosterol and mimosine. Free Radic Biol Med 80: 12-26, 2015.

22. Yue TL, Cheng HY, Lysko PG, McKenna PJ, Feuerstein R, Gu JL, Lysko KA, Davis LL and Feuerstein G: Carvedilol, a new vasodilator and beta adrenoceptor antagonist, is an antioxidant and free radical scavenger. J Pharmacol Exp Ther 263: 92-98, 1992.

23. Sigounas G, Hairr JW, Cooke CD, Owen JR, Asch AS, Weidner DA and Wiley JE: Role of benzo[a]pha]pyrene in generation of clustered DNA damage in human breast tissue. Free Radic Biol Med 49: 77-87, 2010.

24. Siriwardhana N and Wang HC: Precancerous carcinogenesis of human breast epithelial cells by chronic exposure to benzo $[a]$ pyrene. Mol Carcinog 47: 338-348, 2008.

25. Petrulea MS, Plantinga TS, Smit JW, Georgescu CE and NeteaMaier RT: PI3K/Akt/mTOR: A promising therapeutic target for non-medullary thyroid carcinoma. Cancer Treat Rev 41: 707-713, 2015.

26. Su CH, Wang CY, Lan KH, Li CP, Chao Y, Lin HC, Lee SD and Lee WP: Akt phosphorylation at Thr308 and Ser473 is required for CHIP-mediated ubiquitination of the kinase. Cell Signal 23: 1824-1830, 2011.

27. Vincent EE, Elder DJ, Thomas EC, Phillips L, Morgan C, Pawade J, Sohail M, May MT, Hetzel MR and Tavaré JM: Akt phosphorylation on Thr308 but not on Ser 473 correlates with Akt protein kinase activity in human non-small cell lung cancer. Br J Cancer 104: 1755-1761, 2011.
28. Mayo LD and Donner DB: A phosphatidylinositol 3-kinase/Akt pathway promotes translocation of Mdm2 from the cytoplasm to the nucleus. Proc Natl Acad Sci USA 98: 11598-11603, 2001.

29. Umannová L, Machala M, Topinka J, Schmuczerová J, Krčmář P, Neča J, Śujanová K, Kozubík A and Vondráček J: Benzo[a] pyrene and tumor necrosis factor- $\alpha$ coordinately increase genotoxic damage and the production of proinflammatory mediators in alveolar epithelial type II cells. Toxicol Lett 206: 121-129, 2011.

30. Cromie MM, Liu Z and Gao W: Epigallocatechin-3-gallate augments the therapeutic effects of benzo[ $[a]$ pyrene-mediated lung carcinogenesis. Biofactors 43: 529-539, 2017.

31. Pääjärvi G, Jernström B, Seidel A and Stenius U: Anti-diol epoxide of benzo[ $[a]$ pyrene induces transient $\mathrm{Mdm} 2$ and $\mathrm{p} 53$ Ser15 phosphorylation, while anti-diol epoxide of dibenzo[a,l] pyrene induces a nontransient p53 Ser15 phosphorylation. Mol Carcinog 47: 301-309, 2008.

32. Lambert PF, Kashanchi F, Radonovich MF, Shiekhattar R and Brady JN: Phosphorylation of p53 serine 15 increases interaction with CBP. J Biol Chem 273: 33048-33053, 1998.

33. Zhou BP, Liao Y, Xia W, Zou Y, Spohn B and Hung MC: HER-2/neu induces p53 ubiquitination via Akt-mediated MDM2 phosphorylation. Nat Cell Biol 3: 973-982, 2001.

34. Freedman AN, Yu B, Gail MH, Costantino JP, Graubard BI, Vogel VG, Anderson GL and McCaskill-Stevens W: Benefit/risk assessment for breast cancer chemoprevention with raloxifene or tamoxifen for women age 50 years or older. J Clin Oncol 29: 2327-2333, 2011.

35. Hemachandra LP, Patel H, Chandrasena RE, Choi J, Piyankarage SC, Wang S, Wang Y, Thayer EN, Scism RA, Michalsen BT, et al: SERMs attenuate estrogen-induced malignant transformation of human mammary epithelial cells by up-regulating detoxification of oxidative metabolites. Cancer Prev Res (Phila) 7: 505-515, 2014.

36. Balaha M, Kandeel S and Barakat W: Carvedilol suppresses circulating and hepatic IL-6 responsible for hepatocarcinogenesis of chronically damaged liver in rats. Toxicol Appl Pharmacol 311: 1-11, 2016.

This work is licensed under a Creative Commons Attribution-NonCommercial-NoDerivatives 4.0 International (CC BY-NC-ND 4.0) License. 